\title{
DEVELOPING AN ISLAMIC FINANCIAL INCLUSION INDEX FOR ISLAMIC BANKS IN INDONESIA: A CROSS-PROVINCE ANALYSIS
}

\author{
M. Mahbubi Ali ${ }^{1}$, Muhammad Rizky Prima Sakti ${ }^{2}$ and Abrista Devi ${ }^{3}$ \\ ${ }^{1}$ International Institute of Advanced Islamic Studies (IAIS), Malaysia, mahbubiali83@gmail.com \\ ${ }^{2}$ Researcher, Islamic Economic Forum for Indonesian Development (ISEFID), Indonesia, \\ ibnulkhair@gmail.com \\ ${ }^{3}$ Ibn Chaldun Bogor University, Indonesia, abristasmart@gmail.com
}

\begin{abstract}
This study measures an Islamic financial inclusion index in Indonesia based on three dimensions, namely the accessibility, availability and usage of Islamic banking services. Additionally, it measures the relationship between the Islamic financial inclusion index and the human development index (HDI). The study found that the level of Islamic financial inclusion in Indonesia is relatively low at the national level. DKI Jakarta is the most financially inclusive province in Indonesia, followed by East Java and Nanggroe Aceh Darussalam. In contrast, East Nusa Tenggara has the lowest average Islamic financial inclusion index. The findings also revealed a positive correlation between the Islamic financial inclusion index and HDI. Those provinces with the highest Islamic financial inclusion index were also likely to have a higher HDI. The findings of the present study suggest that both policymakers and the Islamic financial industry should play a greater role in improving financial access to low-income segments, especially in the eastern part of Indonesia such as East Nusa Tenggara and Papua provinces.
\end{abstract}

Keywords: Financial Inclusion, Islamic Banks, Indonesia.

JEL Classification: C33; C54; F43.

Article history:

Received : October 20, 2019

Revised : : October 31, 2019

Accepted : : November 6, 2019

Available online : December 27, 2019

https://doi.org/10.21098/jimf.v5i4.1098

Acknowledgment: This paper is part of the research project funded by the Central Bank of Indonesia Bank Indonesia Institute under Resaerch Grandt Bank Indonesia Program 2018. 


\section{INTRODUCTION}

\subsection{Background}

Since the early 2000s, financial inclusion has been a renewed concern for many governments and central banks. The World Bank's 2017 Global Findex Database reported that around 1.7 billion people worldwide do not have an account at a financial institution or through a mobile money provider. The United Nations Development Programme (UNDP) is therefore seeking to incorporate improved financial access into its main development agenda as part of the Sustainable Development Goals (SDGs). A plethora of academic evidence confirms that financial inclusion can support the achievement of broader SDGs.

The last two decades have seen exponential growth in Islamic finance, and it has emerged as one of the fastest-growing financial sectors. According to the 2018 Global Islamic Finance Report (GIFR), the global Islamic financial industry was worth US\$2.431 trillion in 2017 and registered growth of $6.02 \%$. The industry is expected to surpass US $\$ 4$ trillion by 2020 .

As a business entity established within the scope of Shariah principles, Islamic finance aims to promote economic well-being, help in creating socio-economic justice and serve as a catalyst for development, in line with the spirit of the United Nations Agenda for Sustainable Development. The International Monetary Fund (IMF), in its press release dated May 9, 2018, also acknowledged that "the growth of Islamic finance presents important opportunities to strengthen financial inclusion, deepen financial markets, and mobilise funding for development by offering new modes of finance and attracting 'unbanked' populations that have not participated in the financial system."

Mohieldin, Iqbal, Rostom, and Fu (2011) argued that Islamic finance addresses the issue of financial inclusion from two dimensions: Firstly, by promoting the concept of profit and loss sharing (PLS) or risk-sharing as an alternative to conventional debt-based financing. And secondly, through methods of Islamic social finance such as zakat, wakaf, infaq and qard hasan, which complement the PLS instrument.

Over the last two decades, the Islamic financial market in Indonesia has evolved and developed exponentially, emerging as an important jurisdiction in the global Islamic financial industry. The emergence of the Islamic financial market in Indonesia is now expected to play a more significant role in supporting the financial inclusion agenda through PLS-based products, Islamic micro-initiatives and Islamic social programmes. This is particularly the case as financial inclusion forms an important part of a country's national agenda to accelerate economic growth, promote equality of income distribution, reduce poverty and achieve financial stability (Hadad, 2010). On the other hand, Indonesia has a relatively low financial inclusion rate compared to other developing countries. The World Bank's 2017 Global Findex reported that more than half (51.1\%) of Indonesian adults are unbanked. Forty-six per cent of men have an account, which is five per cent less than the proportion of women (51\%) with an account. What makes this study crucial and timely is, to the best of the researchers' knowledge, no study has so far been conducted on an Islamic financial inclusion index for the Islamic banking industry in Indonesia, especially at the provincial level. This study is also undertaken with the aim of supporting the country's aspiration to elevate the 
market share of the Islamic financial industry by increasing the level of Islamic financial inclusion. Thus, there is a need to develop an Islamic financial inclusion index in Indonesia.

Against the above background, the present study undertakes to measure the Islamic financial inclusion index in Indonesia. The remainder of the paper is organised as follows. Section 2 contains a literature review pertaining to the financial inclusion index. Section 3 provides the data, operational definitions of the variables and the calculation methods used. Section 4 presents the empirical results and discussion. Section 5 concludes the paper with a set of policy recommendations.

\subsection{Objective}

Specifically, the present paper aims to achieve the following objectives:

1. To measure the Islamic financial inclusion index in Indonesia based on three dimensions, namely the accessibility, availability and usage of Islamic banking services.

2. To examine the relationship between the Islamic financial inclusion index and HDI.

\section{LITERATURE REVIEW}

\subsection{Background Theory}

Financial inclusion is defined as the delivery of financial access to low-income segments of society at an affordable cost (World Bank, 2014). The term low-income segment can be taken as referring to any of "non-banked", "non-bankable", "nothave people" or poor people (Allen, Demirguc-Kunt, Klapper, \& Peria, 2012; Kunt \& Klapper, 2013; Mohieldin, Iqbal, Rostom, \& Fu, 2011). Kimutai (2015) defines financial inclusion as the provision of banking services to the unbanked population by various financial institutions such as banks and microfinance. Financial inclusion revolves around four dimensions, namely easy access to finance for all households and enterprises, sound financial institutions, financial and institutional sustainability and healthy competition between service providers so that customers have better options (Mohieldin et al., 2011).

Since the early 2000s, financial inclusion has been the focus of renewed concern for many governments and central banks across many jurisdictions. Many embrace financial inclusion as part of their poverty alleviation agenda. A plethora of academic evidence asserts that financial inclusion can have a positive significant impact on individuals, particularly with regard to the use of a bank account. It is argued that having a bank account increases savings (Aportela, 1999), female empowerment (Ashraf et al., 2010) and consumption, as well as the productive investment of entrepreneurs (Dupas \& Robinson, 2013). In contrast, the lack of a bank account leads to liquidity management and payment problems, thereby resulting in high fees associated with the use of money orders or cheque-cashing services (Lusardi, 2010). From a broader perspective, lack of access to finance for the low-income segment might trigger their entry into the "poverty trap" as they 
do not have the opportunity to save when there is a liquidity excess or to borrow when they have to endure starvation (Mohieldin et al., 2011).

The spirit of financial inclusion corresponds with the philosophical foundation of Islamic finance to realise social justice and the sharing of resources among all. The IMF, in its press release dated May 9, 2018, acknowledged that "the growth of Islamic finance presents important opportunities to strengthen financial inclusion, deepen financial markets, and mobilise funding for development by offering new modes of finance and attracting 'unbanked' populations that have not participated in the financial system".

Nevertheless, relatively few studies have been conducted to examine the role of Islamic finance in financial inclusion. Hassan (2015) discussed the role of the Islamic microfinance system in India in the context of financial inclusion. According to the author, mainstream microfinance does not accommodate the needs of underserved Muslims in India. The paper summarised several obstacles faced by the mainstream microfinance institutions in improving financial inclusion: (i) high documentation and procedures, (ii) high transaction costs, (iii) inflexibility and delay and (iv) social obligation. The author believes that Islamic microfinance has a substantial role to play in the promotion of financial inclusion. Other research found that Muslim countries have a low proportion of bank accounts (27\%), with only $15 \%$ of adults in sub-Saharan Africa holding accounts in formal financial institutions (Zulkhibri, 2016). The author argues that the poor in Muslim countries who lack access to financial services will continue to be trapped in poverty.

The importance of a risk-sharing system in improving financial inclusion has been studied by Zulkhibri (2016), Shaikh (2017) and Bongomin, Munene, Ntayi, and Maling (2018). Zulkhibri (2016) studied whether Islamic finance can improve financial inclusion. The author concluded that the features of risksharing and redistribution of wealth embedded in Islamic finance can advance financial inclusion through the promotion of microfinance and SME financing. The promotion of risk-sharing contracts through Islamic microfinance, which are a viable alternative to debt-based financing contracts, can support the economic activity of the poor and needy groups in Muslim countries and thus improve their productivity. This was supported by Hassan (2015), who also noted that the notion of risk-sharing in an Islamic microfinance system could enhance the level of financial inclusion and promote equality. Similarly, Shaikh (2017) cited that the risk-sharing and asset-backed nature of Islamic microfinance institutions can increase the level of financial inclusion.

Mohieldin et al. (2011) argued that Islamic finance addresses the issue of financial inclusion or access to financial services from two dimensions. Firstly, by promoting the concept of profit- and loss-sharing as an alternative to conventional debt-based financing and secondly, through wealth redistribution instruments such as zakat, sadaqah (alms), waqf (endowment fund) and qard hasan (benevolent loan), which complement the PLS instrument within the poverty eradication agenda.

PLS promotes the financial inclusion agenda as it can offer affordable and fair financial access to low-income segments: the imposition of cost and the distribution of profit are based on the actual performance of the business. As a result, the optimum application of PLS will help to create an equitable distribution of 
income and wealth among partners or between wealth owners and entrepreneurs, thereby presenting the concept of justice and fairness in financial dealings. Risk transfer underlying the conventional financial system, on the other hand, implies asymmetric exposure to economic risk and does not therefore promote economic justice and financial inclusion. Instead, it serves only to create a continuous transfer of wealth from entrepreneur to wealth owner, irrespective of economic downturns and business performance.

Furthermore, social finance, mandated or otherwise, is an integral part of the Islamic financial system to offer equal opportunity to financial access for lowincome segments, i.e. the underserved and poor, "so that it may not (merely) make a circuit between the wealthy among you" (QS 59:7). Islamic social finance instruments help to improve those segments' financial access via various initiatives and strategies, such as microfinance empowerment, poverty alleviation schemes and educational and entrepreneurship development programmes.

Financial technology (fintech) is the perfect device for reinforcing the role of Islamic finance in promoting the financial inclusion agenda. The use of digital finance, such as blockchain and crowdfunding, can lower transaction costs and minimise asymmetric information. Santander FinTech issued a report in 2015 estimating that blockchain could reduce the transaction costs attributable to crossborder payment, securities trading and regulatory compliance by between US\$15 billion (RM62 billion) and US\$20 billion per annum by 2022.

Furthermore, blockchain's ability to transmit and record the ownership of digital assets and immutably store information - where all blockchain participants have access to the same information - might significantly reduce information asymmetries. Fintech can also open up financial access to unbanked individuals. According to a World Bank estimate, there are approximately 240 million to 334 million people in developing economies that could participate in crowdfunding. Fintech is also a powerful tool for widening the access to and outreach of Islamic social finance instruments such as zakah, waqf and sadaqah.

\subsection{Previous Studies}

Traditionally, financial inclusion has been measured as the proportion of the population covered by commercial bank branches and ATMs, the size of deposits and loans by low-income households and SMEs (Mohieldin et al., 2011). Allen, Demirguc-Kunt, Klapper, and Peria (2012) argued that the bank account is the primary indicator of financial inclusion. It can be measured using three indicators: (i) ownership of an account, (ii) use of the account to save, and (iii) frequent use of the account (defined as three or more withdrawals per month). In a similar vein, Zins and Weill (2016), in their study, used ownership of a bank account, saving in a bank account and the use of bank credit as indicators of financial inclusion. The Global Financial Inclusion Database survey (Kunt \& Klapper, 2012) investigated several factors with respect to bank account use, namely: (i) the mechanism of their use (frequency of use and mode of access); (ii) their purpose (receipt of payments from work, government or family); and (iii) barriers to use and alternatives to formal accounts (mobile money). 
Furthermore, Naceur, Barajas, and Massara (2015) classified the users of financial services into two, namely household users and firm users. The following indicators were used to measure the extent of household users' access to finance: (i) loans from formal financial institutions; (ii) ownership of an account at a formal financial institution; and (iii) religious reasons for not having an account. Measurement of financial inclusion for the firm was based on the following indicators: (i) the use of a bank for investment; (ii) the use of a bank for working capital; and (iii) access to finance as a significant constraint. Kimutai (2015) used various indicators to measure financial inclusion, namely daily transactions, the number of registered account holders and active account holders.

Kunt and Klapper (2013) concluded that the ownership and use of accounts were the typical financial inclusion indicators used across jurisdictions. The ownership and use of accounts are relatively easy to define and observe, which is particularly true since basic current and savings accounts share relatively common features and characteristics across countries.

Sarma (2012) introduced a method of computing an Index of Financial Inclusion (IFI) to compare the levels of financial inclusion across states or provinces within countries over a particular time period. The method fulfils the assumptions of comparability, mathematical properties and three dimensions (accessibility, availability and the use of a banking service). The indicator of accessibility represents the penetration of formal financial institutions as measured by the total of third-party deposits. The availability variable is indicated by the number of banking branches while the usage dimension includes the volume of credit/financing per total household sector. A similar study was carried out by Sanjaya and Nursechafia (2016), who measured the role of conventional banking in financial inclusion and the level of inclusive growth in Indonesia, while Umar (2017) calculated an Islamic financial inclusion index in Indonesia for Islamic rural banks (BPRS).

The present study develops the Islamic financial index in Indonesia based on the indicators advanced by Sarma (2012). It aims to fill the gap in the existing literature by measuring the Islamic financial inclusion index in Indonesia for Islamic commercial banks (BUS) and Islamic business units (UUS) based on three dimensions, namely accessibility, availability and the use of Islamic banking products and services. This study differs from that by Umar (2017) who only used Islamic rural banks as the sampling in the measurement of Islamic financial inclusion in Indonesia. It also differs from the study by Sanjaya and Nursechafia (2016), who measured the financial inclusion index based on conventional banks.

\section{RESEARCH METHODOLOGY}

\subsection{Data}

In developing the Islamic financial inclusion index, this research employs Islamic banking information and several macroeconomic indicators from across $\mathrm{w}$ Indonesia for the period 2014 to 2017. The information pertaining to third-party funds, total financing and the total branches of Islamic banks across 33 provinces were retrieved from the Financial Services Authority of Indonesia (OJK). The total population and regional gross domestic product (GDP regional) data were 
obtained from the Central Bureau of Statistics (Indonesia). To analyse the data, we use Stata 13.0 and Microsoft Excel. Referring to Sarma (2012), we use three dimensions in measuring the Islamic financial inclusion index, namely accessibility (D1), availability (D2) and usage (D3). We also analyse the relationship between the Islamic financial inclusion index and the human development index (HDI) across 33 provinces. The HDI information was retrieved from the Central Bureau of Statistics of Indonesia. To provide a complete picture of the variables or proxies used in this study, Table 1 below contains the operational definitions of each variable.

Table 1.

Operational definitions of the Islamic Financial Inclusion Index and Human Development Index (HDI)

\begin{tabular}{|c|c|c|c|}
\hline No & Variable & Description & Calculation \\
\hline \multicolumn{4}{|c|}{ Measurement of Islamic Financial Inclusion Index } \\
\hline 1 & Accessibility (D1) & $\begin{array}{l}\text { The accessibility } \\
\text { dimension measures } \\
\text { the level of Islamic } \\
\text { banking penetration to } \\
\text { low-income people. }\end{array}$ & $D 1=\frac{\text { The total of third party funds in IB }}{\text { Total population }} \times 1,000$ \\
\hline 2 & Availability (D2) & $\begin{array}{c}\text { This dimension } \\
\text { measures the level of } \\
\text { availability of Islamic } \\
\text { banking services for } \\
\text { use by low-income } \\
\text { people. }\end{array}$ & $D 2=\frac{\text { The total of IB Branches }}{\text { Total population }} \times 100,000$ \\
\hline 3 & Usage (D3) & $\begin{array}{l}\text { This dimension } \\
\text { measures the extent to } \\
\text { which Islamic banking } \\
\text { products and services } \\
\text { can satisfy customers' } \\
\text { needs, i.e. the need for } \\
\text { Islamic financing. }\end{array}$ & $D 3=\frac{\text { The total of IB Financing }}{\text { GDP Regional }} \times 1,000$ \\
\hline 4 & $\begin{array}{l}\text { Islamic financial } \\
\text { inclusion index }\end{array}$ & & $\mathrm{D} 1+\mathrm{D} 2+\mathrm{D} 3$ \\
\hline 5 & $\begin{array}{l}\text { Human } \\
\text { development } \\
\text { index }\end{array}$ & $\begin{array}{r}\text { A statistical tool for } \mathrm{m} \\
\text { economic dimension } \\
\text { retrieved from }\end{array}$ & $\begin{array}{l}\text { easuring overall achievement across key social and } \\
\text { s. The HDI ratio across } 33 \text { provinces in Indonesia, } \\
\text { the Central Bureau of Statistics (Indonesia). }\end{array}$ \\
\hline
\end{tabular}

Source: adopted from Sarma (2012)

\subsection{Model Development and Method}

The Islamic financial inclusion index is constructed based on three dimensions, namely: (i) accessibility, (ii) availability and (iii) usage. The first dimension of accessibility (D1) reflects the level of penetration of Islamic banking institutions. The availability dimension (D2) is measured by the number of Islamic banking branches. The usage dimension (D3) indicates the total Islamic banking financing 
per total GDP regional. The equation below formulates the financial inclusion dimensions:

$$
d_{i}=w_{i} \frac{A_{i}-m_{i}}{M_{i}-m_{i}}
$$

where:

$w_{i}=$ weight attached to dimension $i$

$A_{i}=$ actual value of dimension $i$

$m_{i}=$ lower limit on the value of dimension $i$

$M_{i}=$ upper limit on the value of dimension $i$

Following Sarma's (2012) method, this study applies equal weight to each dimension $\left(w_{i}=1\right)$. According to Sarma (2012), all dimensions share the same level of significance; therefore, we use a weighted value $w_{i}=1$ for all $i$. If a dimension has a value close to $w_{i^{\prime}}$ this indicates an area with the highest achievement across all dimensions. As for the upper and lower limits $\left(M_{i}\right.$ and $\left.m_{i}\right)$, since there are no outlier results in the case of Islamic banking in Indonesia, the point $M_{i}$ represents the maximum value from the available data, while $m_{i}$ represents the minimum value.

Next, we calculate the values of $X_{1}$ and $X_{2}$. While $X_{1}$ gives the normalised Euclidean distance of $X$ from the worst point $0, X_{2}$ shows the normalised Euclidean distance of $X$ from the ideal point of $w$. The formulas for $X_{1}$ and $X_{2}$ are

$$
X_{1}=\frac{\sqrt{d_{1}^{2}+d_{2}^{2}+d_{3}^{2}}}{\sqrt{w_{1}^{2}+w_{2}^{2}+w_{3}^{2}}}
$$

shown in Equations 2 and 3, respectively.

$$
X_{2}=\frac{\sqrt{\left(w_{1}-d_{1}\right)^{2}+\left(w_{2}-d_{2}\right)^{2}+\left(w_{3}-d_{3}\right)^{2}}}{\sqrt{w_{1}^{2}+w_{2}^{2}+w_{3}^{2}}}
$$

The simple average of $X_{1}$ and $X_{2}$ is shown in Equation 4 below.

$$
I F I=\frac{1}{2}\left[X_{1}+X_{2}\right]
$$

The index value of each dimension ranges between 0 and $w_{i}$. A higher value of $d_{i}$ indicates a more ideal point of dimension $i$. Point $X=\left(d_{1}, d_{2}, d_{3}\right)$ represents the achievement of financial inclusion for each province in Indonesia, while 
Point $\mathrm{O}=(0,0,0)$ indicates the worst situation. The most ideal situation for all dimensions is represented by point $\mathrm{W}=\left(w_{1}, w_{2}, w_{3}\right)$. Figure 1 below contains a threedimensional graph of the three aspects of the Islamic financial inclusion index.

\section{Figure 1. A Three-dimensional view of the Islamic Financial Inclusion Index}

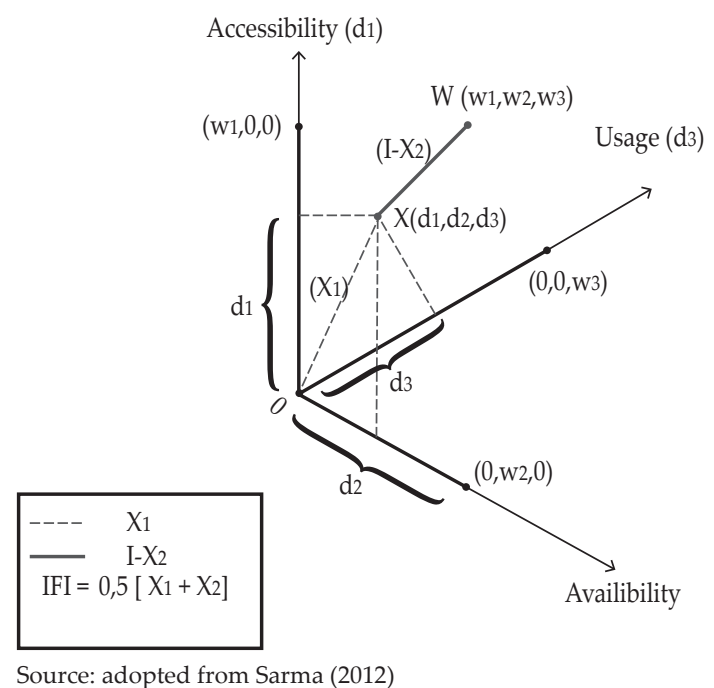

The final step is to calculate the financial inclusion index using the formula in Equation 5 below. The financial inclusion index formula is obtained by taking the average value of $X_{1}$ and $X_{2}$, which represents the position between the worst and the ideal point.

$$
I F I=\frac{1}{2}\left[\frac{\sqrt{d_{1}^{2}+d_{2}^{2}+d_{3}^{2}}}{\sqrt{3}}+\left(1-\frac{\sqrt{\left(1-d_{1}\right)^{2}+\left(1-d_{2}\right)^{2}+\left(1-d_{3}\right)^{2}}}{\sqrt{3}}\right)\right]
$$

Subsequently, the following Equation 6 formulates the estimation model for the relationship between IFI and HDI based on Pearson's correlation coefficient:

$$
r=\frac{\mathrm{N}(\Sigma \mathrm{XY})-(\Sigma \mathrm{X})(\Sigma \mathrm{Y})}{\sqrt{\mathrm{N} \Sigma \mathrm{X}^{2}}-(\mathrm{N} \Sigma \mathrm{X})^{2} \sqrt{\mathrm{N} \Sigma \mathrm{Y}^{2}}-(\Sigma \mathrm{Y})^{2}}
$$

$\mathrm{r} \quad=$ Pearson's correlation coefficient

$\mathrm{N}=$ Number of paired scores

$\Sigma X Y=$ Sum of paired scores

$\Sigma X=$ Sum of $X$ scores

$\Sigma Y \quad=$ Sum of $y$ scores 
$\Sigma X^{2} \quad=$ Sum of squared $x$ scores

$\Sigma Y^{2} \quad=$ Sum of squared $y$ scores

Source: Chee, 2015

\section{RESULTS AND ANALYSIS}

This section presents the empirical findings of the study with the following focus: (i) measuring the three dimensions of Islamic financial inclusion at the national and provincial levels, (ii) calculating the Islamic financial inclusion index and analysing it across the provincial level, and (iii) analysing the relationships between the Islamic financial inclusion index and HDI across provinces.

\subsection{Descriptive Statistics of the Three Dimensions of Islamic Financial Inclusion}

Table 2 contains the descriptive statistics of the three dimensions of Islamic financial inclusion across the 33 provinces in Indonesia. The table presents various statistical indicators, comprising minimum (min), maximum (max), average (mean) and standard deviation (std. dev). At first glance, we notice that the average values of the three dimensions of Islamic financial inclusion (accessibility, availability and usage) vary across the observed study period (2014-2017).

Table 2.

Descriptive Statistics of Islamic Financial Inclusion on Three Dimensions

\begin{tabular}{|c|c|c|c|c|c|}
\hline \multicolumn{6}{|c|}{ Accessibility (D1) } \\
\hline Stat. & 2014 & 2015 & 2016 & 2017 & Average \\
\hline Min & 0.026 & 0.028 & 0.025 & 0.027 & 0.025 \\
\hline $\operatorname{Max}$ & 11.530 & 11.138 & 13.238 & 15.925 & 15.925 \\
\hline Mean & 0.918 & 0.901 & 1.107 & 1.312 & 1.060 \\
\hline Std. Dev. & 2.121 & 2.052 & 2.437 & 2.948 & 2.394 \\
\hline \multicolumn{6}{|c|}{ Availability (D2) } \\
\hline Stat. & 2014 & 2015 & 2016 & 2017 & Average \\
\hline Min & 0.102 & 0.096 & 0.094 & 0.094 & 0.094 \\
\hline Max & 8.161 & 7.067 & 6.469 & 6.387 & 8.161 \\
\hline Mean & 1.358 & 1.143 & 1.105 & 1.099 & 1.176 \\
\hline Std. Dev. & 1.454 & 1.257 & 1.225 & 1.215 & 1.281 \\
\hline \multicolumn{6}{|c|}{ Usage (D3) } \\
\hline Stat. & 2014 & 2015 & 2016 & 2017 & Average \\
\hline Min & 1.888 & 1.655 & 1.338 & 1.082 & 1.082 \\
\hline Max & 59.664 & 61.174 & 113.286 & 115.665 & 115.665 \\
\hline Mean & 18.177 & 17.610 & 21.102 & 22.604 & 19.9 \\
\hline Std. Dev. & 12.541 & 12.823 & 21.240 & 22.323 & 17.742 \\
\hline
\end{tabular}

Source: Author's Calculation (2018) 
In terms of accessibility (D1), Table 2 indicates that there was a gradual increase in the average value of third-party funds of Islamic banks (including Islamic commercial banks and Islamic business units) from IDR 918 million in 2014 to IDR 1.31 billion in 2017. From 2014 to 2017, the mean value of third-party funds per 1,000 people was IDR 1.06 billion. Looking at the third-party funds of Islamic banks across provinces, DKI Jakarta appears to have the highest third-party funds of Islamic banks among all the provinces in Indonesia, followed by East Java (see Figure 1). As a comparison, DKI Jakarta has average third-party funds of IDR 12.95 billion per 1,000 people, while the figure for East Java is IDR 5.96 billion per 1,000 people. Meanwhile, North Sulawesi records the lowest figure on the accessibility level, with IDR 27 million per 1,000 people.

Figure 2.

Accessibility Dimension (D1) across 33 Provinces in Indonesia

Accessibility Dimension (D1)

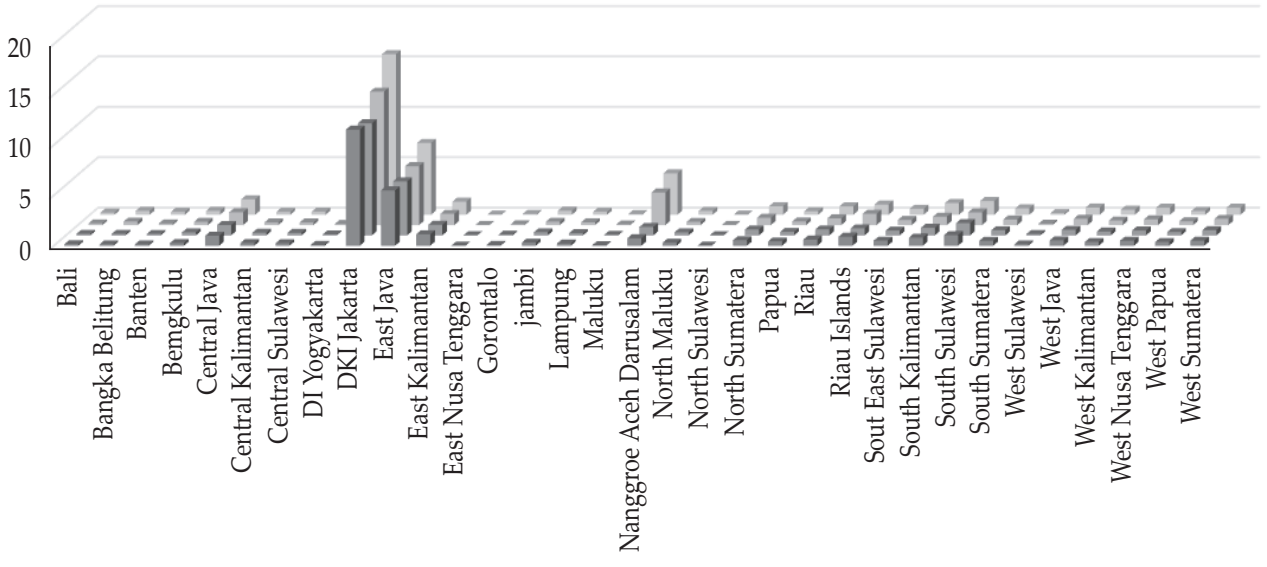

$2014-2015-2016-2017$

Source: Author's Calculation (2018)

With regard to the availability dimension (D2), the average Islamic banking penetration per 100,000 people is 1.17 units. This is based on the notion that one (1) Islamic banking institution can serve 100,000 people in Indonesia. Needless to say, there is very low availability of Islamic banking services to meet the demand of customers. As indicated earlier, the availability dimension is measured by the total distribution of Islamic banking networks, including the operational head office, branch offices, sub-branch offices, shariah services units and cash offices. Looking at the province level, East Java appears to have the highest Islamic banking penetration of 7.02 units per 100,000 people, followed by DKI Jakarta and Nanggroe Aceh Darussalam, with average Islamic banking penetration values of 3.13 units and 2.27 units per 100,000 people, respectively (see Figure 2). The average availability dimension of those provinces exceeds the overall average values of Islamic banking penetration by a significant degree. 


\section{Figure 3. Availability Dimension (D2) across 33 Provinces in Indonesia}

\section{Availability Dimension (D2)}

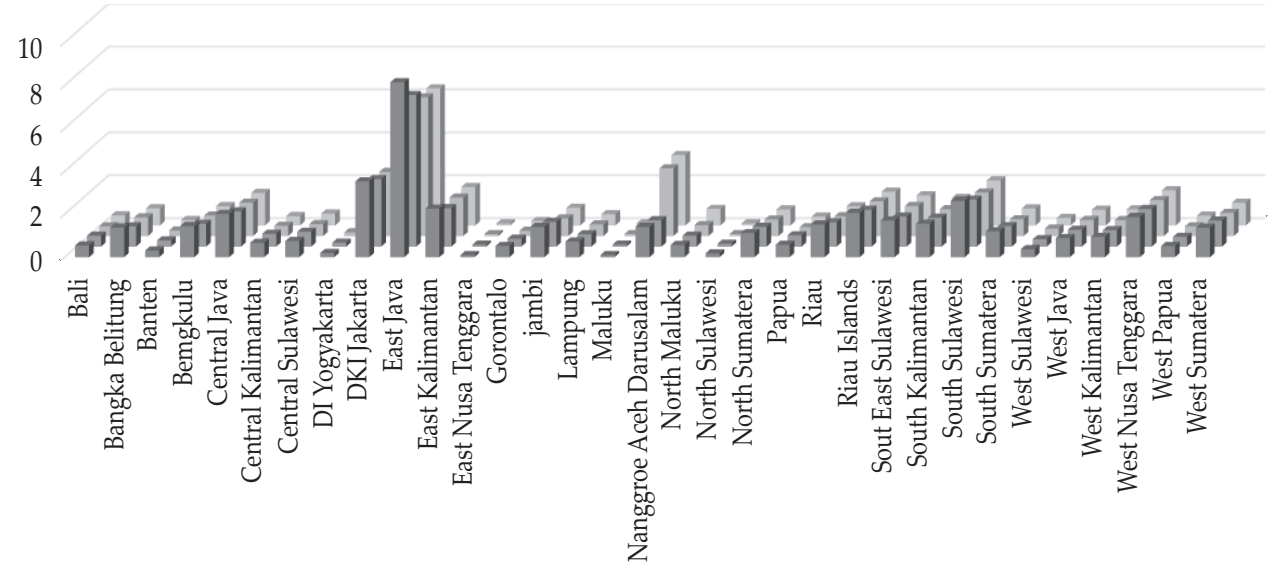

$2014 \square 2015 \square 2016 \square 2017$

Source: author's calculation (2018)

As for the usage dimension (D3), the proportion of Islamic bank financing to GDP regional (PDRB) had an average value of IDR 19.9 billion during the period 2014-2017. The proportion of Islamic bank financing covers the total financing of Islamic commercial banks, Islamic business units and Islamic rural banks. The usage dimension (D3) measures the extent to which Islamic banking institutions can provide various products to their customers, such as financing facilities, deposits, remittances, transfer and others. Also, we notice a variation in terms of the use of Islamic banking services among the 33 provinces in Indonesia.

The result from Figure 3 reveals that the average value of Islamic banking financing to GDP regional ranges between 1.54 and 70.46. Typically, Nanggroe Aceh Darussalam appears to have the highest usage of Islamic banking services with average financing of IDR 70.46 billion from 2014 to 2017, followed by DKI Jakarta and South Sulawesi with average financing of IDR 65.52 billion and IDR 41.74 billion in the period 2014-2017, respectively. East Nusa Tenggara, meanwhile, has the lowest usage of Islamic banking services with average financing of IDR 1.54 billion from 2014 to 2017. It is important to note that the conversion of Bank Aceh to a full-fledged shari'ah-compliant bank in 2016 has significantly increased the amount of Islamic banking financing in Nanggore Aceh Darussalam. Accordingly, the usage of Islamic banking services for Aceh province in 2016 showed a more than fourfold increase over that of the preceding year (2015). 
Figure 4. Usage Dimension (D3) across 33 Provinces in Indonesia

Usage Dimension (D3)

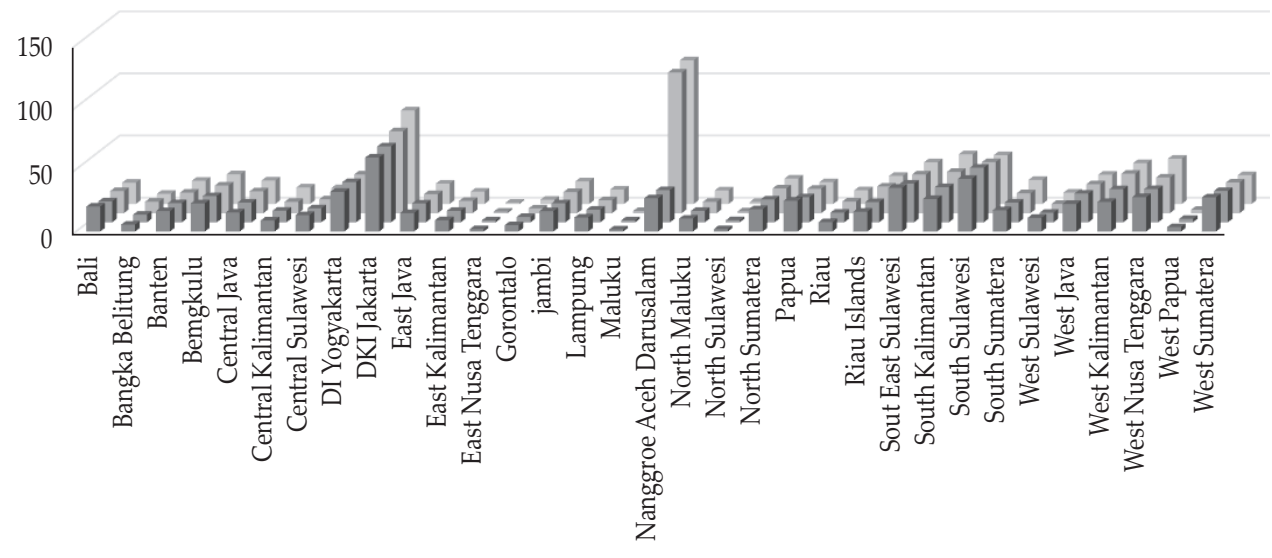

Source: author's calculation (2018)

\subsection{The Islamic Financial Inclusion Index}

Having discussed the descriptive statistics pertaining to the three dimensions of Islamic financial inclusion, this sub-section deals with the development of an index of Islamic financial inclusion. Table 3 below contains the minimum value (min), maximum (max), average (mean) and standard deviation (std. dev.) of each component in the Islamic financial inclusion index.

Table 3.

Descriptive Statistics of the Islamic Financial Inclusion Index

\begin{tabular}{lccccc}
\hline \multicolumn{5}{c}{ Accessibility Index (d1) } \\
\hline Stat. & $\mathbf{2 0 1 4}$ & $\mathbf{2 0 1 5}$ & $\mathbf{2 0 1 6}$ & $\mathbf{2 0 1 7}$ & Average \\
\hline Min & 0.000 & 0.000 & 0.000 & 0.000 & 0.000 \\
Max & 0.724 & 0.699 & 0.831 & 1.000 & 1.000 \\
Mean & 0.056 & 0.055 & 0.068 & 0.081 & 0.065 \\
Std. Dev. & 0.133 & 0.129 & 0.153 & 0.185 & 0.151 \\
\hline \multicolumn{5}{c}{ Availability Index (d2) } \\
\hline Stat. & $\mathbf{2 0 1 5}$ & $\mathbf{2 0 1 6}$ & $\mathbf{2 0 1 7}$ & Average \\
\hline Min & $\mathbf{2 0 1 4}$ & 0.000 & 0.000 & 0.000 & 0.000 \\
Max & 0.001 & 0.864 & 0.790 & 0.780 & 1.000 \\
Mean & 1.000 & 0.130 & 0.125 & 0.125 & 0.134 \\
Std. Dev. & 0.157 & 0.156 & 0.152 & 0.151 & 0.159 \\
\hline \multicolumn{7}{c}{ Usage Index (d3) } \\
Stat. & 0.180 & $\mathbf{2 0 1 5}$ & $\mathbf{2 0 1 6}$ & $\mathbf{2 0 1 7}$ & Average \\
\hline Min & $\mathbf{2 0 1 4}$ & 0.005 & 0.002 & 0.000 & 0.000 \\
Max & 0.007 & 0.524 & 0.979 & 1.000 & 1.000 \\
Mean & 0.511 & 0.144 & 0.175 & 0.188 & 0.164 \\
Std. Dev. & 0.149 & 0.112 & 0.185 & 0.195 & 0.155 \\
\hline
\end{tabular}

Source: author's calculation (2018) 
Based on Table 3, the study finds that the usage index (D3) has the highest average value of 0.164 during the period 2014-2017, followed by the availability (D2) and accessibility index (D1) with average values of 0.134 and 0.065 , respectively. These results indicate that the usage and availability dimensions play a crucial role as the determinants of Islamic financial inclusion in Indonesia. The highest average figure for the usage dimension also reveals that Islamic banking institutions in Indonesia performed well in channelling their financing to their customers. As financial intermediaries, Islamic banks provide numerous products to their customers, including financing facilities, deposits, remittances, transfer, etc. In contrast, the lowest average values are seen for the accessibility dimension of Islamic banks, suggesting that accessibility is the least important dimension in affecting the level of Islamic financial inclusion.

According to past studies (Allen et al., 2012; Beck et al., 2008; Sarma, 2012), the distance to access banking services has led to people being financially excluded. Great distances between people and bank branches, especially in rural areas, serve as the main obstacle to financial access. Providing financial services to consumers living in rural areas is one of the main challenges facing Islamic financial institutions due to the inadequate infrastructure, low levels of IT development and regulatory restrictions on the geographical expansion of bank branches (Zulkhibri, 2016). This results in a situation where customers do not have access to a full set of Islamic banking services in a convenient manner. On this basis, the average level of the Islamic financial inclusion index from the accessibility dimension (D1) in Indonesia is relatively low, at only 0.065 (see Table 3).

Furthermore, the study observes an unequal distribution of the third-party funds of Islamic banks across the 33 provinces studied (see Figure 4). The level of third-party funds of Islamic banking in the eastern part of Indonesia is significantly lower than that in the western part. Specifically, provinces on Java island such as DKI Jakarta, West Java and East Java had the highest average third-party funds from 2014 to 2017, at IDR 130 trillion, IDR 28 trillion and IDR 21 trillion, respectively. On the other hand, East Nusa Tenggara, West Sulawesi and Gorontalo recorded the lowest average third-party funds, with only IDR 123 billion, IDR 170 billion and IDR 216 billion, respectively. 
Figure 5.

Third Party Funds (DPK) of Islamic banks across 33 Provinces in Indonesia

Third Party Funds Of Islamic Banks

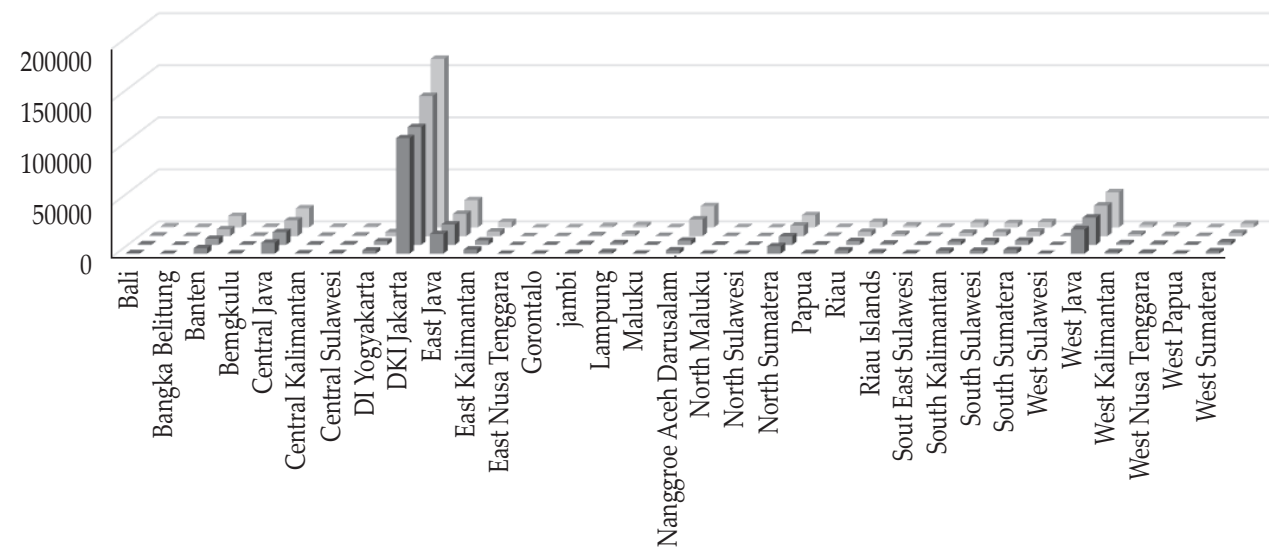

Source: Financial Services Authority of Indonesia (2018)

In a similar vein, the result reveals that the distribution of Islamic bank branches is highly concentrated on Java island (particularly in West Java, DKI Jakarta and East Java) (see Figure 5). Other provinces, particularly in the eastern part of Indonesia, have a relatively low number of Islamic bank branches. It is therefore more challenging for Islamic financial services to penetrate to the eastern part of Indonesia due to the lack of supporting infrastructure and the long distances between communities and bank branches.

Figure 6. The Distribution of Islamic Commercial Banks and Islamic Business Units across 33 Provinces in Indonesia

Total Branches of Islamic Commercial Banks \& Islamic Business Unit

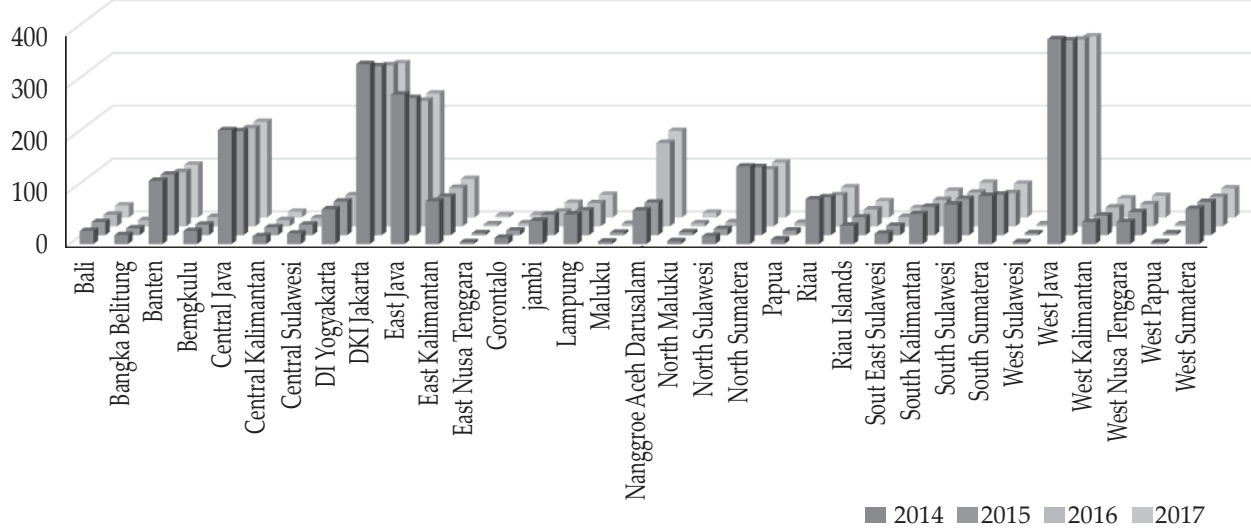


More importantly, the crux of the Islamic financial inclusion index is shown in Table 4 and Figure 6 below, respectively. Overall, the study discovers that the total average Islamic financial inclusion index in Indonesia from 2014 to 2017 was very low, at only 0.127 . Accordingly, most Indonesian provinces have a low level of Islamic financial inclusion index, especially in the eastern part of Indonesia. Nevertheless, there was a positive move in the Islamic financial inclusion index during the period 2014-2017, shifting from 0.128 in 2014 to 0.136 in 2017. This finding, to a significant extent, confirms the latest report by the Global Financial Inclusion Index (World Bank, 2018) that Indonesia was the most progressive country in terms of its financial inclusion agenda across East Asia and the Pacific region over the past three years. The World Bank (2018), in its report, also acknowledged that Indonesia saw the biggest increase in account ownership in the East Asia and Pacific region.

Table 4.

Index of Islamic Financial Inclusion across 33 Provinces in Indonesia

\begin{tabular}{|c|c|c|c|c|c|}
\hline \multicolumn{6}{|c|}{ Index of Islamic Financial Inclusion in Indonesia } \\
\hline Provinces & 2014 & 2015 & 2016 & 2017 & Average \\
\hline Bali & 0.088 & 0.075 & 0.077 & 0.076 & 0.079 \\
\hline Bangka Belitung & 0.081 & 0.059 & 0.066 & 0.060 & 0.067 \\
\hline Banten & 0.068 & 0.063 & 0.066 & 0.076 & 0.068 \\
\hline Bengkulu & 0.134 & 0.113 & 0.113 & 0.117 & 0.119 \\
\hline Central Java & 0.149 & 0.133 & 0.138 & 0.144 & 0.141 \\
\hline Central Kalimantan & 0.055 & 0.053 & 0.047 & 0.061 & 0.054 \\
\hline Central Sulawesi & 0.073 & 0.063 & 0.057 & 0.063 & 0.064 \\
\hline DI Yogyakarta & 0.122 & 0.123 & 0.119 & 0.130 & 0.124 \\
\hline DKI Jakarta & 0.552 & 0.533 & 0.580 & 0.643 & 0.577 \\
\hline East Java & 0.491 & 0.450 & 0.436 & 0.459 & 0.459 \\
\hline East Kalimantan & 0.149 & 0.124 & 0.126 & 0.129 & 0.132 \\
\hline East Nusa Tenggara & 0.004 & 0.002 & 0.001 & 0.000 & 0.002 \\
\hline Gorontalo & 0.034 & 0.024 & 0.017 & 0.014 & 0.022 \\
\hline Jambi & 0.113 & 0.097 & 0.089 & 0.094 & 0.098 \\
\hline Lampung & 0.065 & 0.055 & 0.055 & 0.058 & 0.058 \\
\hline Maluku & 0.004 & 0.003 & 0.004 & 0.006 & 0.004 \\
\hline Nanggroe Aceh Darussalam & 0.152 & 0.144 & 0.517 & 0.543 & 0.339 \\
\hline North Maluku & 0.056 & 0.050 & 0.049 & 0.067 & 0.056 \\
\hline North Sulawesi & 0.008 & 0.004 & 0.002 & 0.002 & 0.004 \\
\hline North Sumatera & 0.108 & 0.102 & 0.103 & 0.106 & 0.105 \\
\hline Papua & 0.110 & 0.091 & 0.085 & 0.077 & 0.091 \\
\hline Riau & 0.099 & 0.079 & 0.075 & 0.080 & 0.083 \\
\hline Riau Islands & 0.152 & 0.133 & 0.150 & 0.149 & 0.146 \\
\hline South East Sulawesi & 0.189 & 0.163 & 0.163 & 0.172 & 0.172 \\
\hline South Kalimantan & 0.158 & 0.155 & 0.169 & 0.198 & 0.170 \\
\hline South Sulawesi & 0.257 & 0.247 & 0.232 & 0.230 & 0.242 \\
\hline South Sumatera & 0.109 & 0.094 & 0.087 & 0.101 & 0.098 \\
\hline West Sulawesi & 0.049 & 0.036 & 0.035 & 0.041 & 0.040 \\
\hline West Java & 0.113 & 0.113 & 0.113 & 0.115 & 0.113 \\
\hline West Kalimantan & 0.119 & 0.122 & 0.141 & 0.146 & 0.132 \\
\hline West Nusa Tenggara & 0.171 & 0.163 & 0.167 & 0.193 & 0.173 \\
\hline West Papua & 0.034 & 0.028 & 0.029 & 0.028 & 0.030 \\
\hline West Sumatera & 0.150 & 0.136 & 0.130 & 0.125 & 0.135 \\
\hline Average Total & 0.128 & 0.116 & 0.128 & 0.136 & 0.127 \\
\hline
\end{tabular}

Source: author's calculation (2018) 
As for the Islamic financial inclusion index at the province level, DKI Jakarta recorded the highest average Islamic financial inclusion index for 2014-2017, at 0.577. During that period, DKI Jakarta recorded the greatest increase in Islamic financial inclusion, moving from 0.552 in 2014 to 0.643 in 2017. East Java and Nanggroe Aceh Darussalam occupied the second and third ranks of Islamic financial inclusion with average values of 0.459 and 0.339 , respectively. Apparently, East Java was able to occupy the second position in the Islamic financial inclusion index due to it having the highest Islamic banking penetration per 100,000 people (see Figure 2). Meanwhile, as argued earlier, the conversion of Bank Aceh into a full-fledged shari'ah-compliant bank in 2016 led to a remarkable increase in the Islamic financial inclusion index score in Nanggore Aceh Darussalam. In contrast, East Nusa Tenggara had the lowest average Islamic financial inclusion index score, at only 0.002 . This was mainly due to it registering the lowest Islamic banking penetration and usage of Islamic banking services in the province. Figure 6 exhibits the top 10 rankings for the Islamic financial inclusion index in Indonesia.

Figure 7.

Top 10 Index of Islamic Financial Inclusion in Indonesia

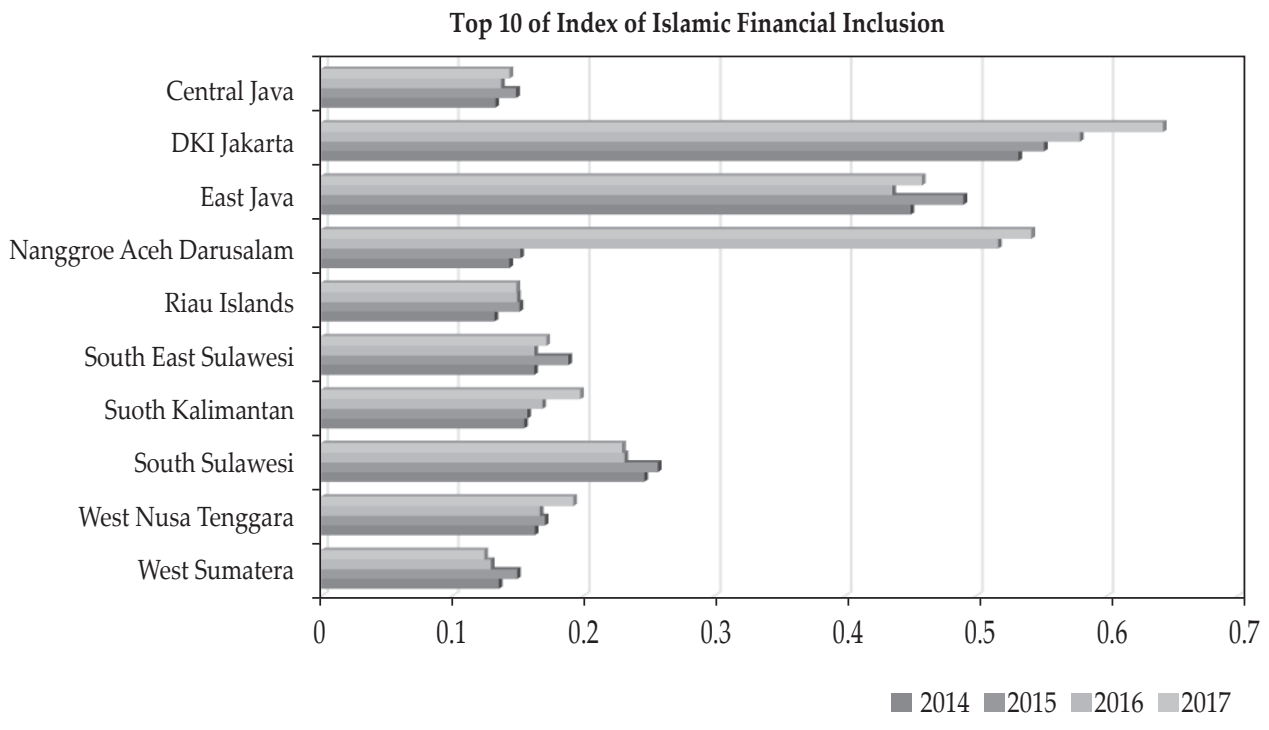

Source: author's calculation (2018)

\subsection{The Islamic Financial Inclusion Index and Human Development Index}

The following sub-section investigates the correlation between the Islamic financial inclusion index and HDI across 33 provinces in Indonesia. Information pertaining to the HDI was retrieved from the Central Bureau of Statistics (Indonesia). Table 5 depicts the distribution of HDI across the 33 provinces from 2014 to 2017. 
Table 5.

Human Development Index across 33 Provinces in Indonesia

\begin{tabular}{lccccc}
\hline & Human Development Index in Indonesia & & \\
\hline Provinces & $\mathbf{2 0 1 4}$ & $\mathbf{2 0 1 5}$ & $\mathbf{2 0 1 6}$ & $\mathbf{2 0 1 7}$ & Average \\
\hline Bali & 72.48 & 73.27 & 73.65 & 74.30 & 73.43 \\
Bangka Belitung & 68.27 & 69.05 & 69.55 & 69.99 & 69.22 \\
Banten & 69.89 & 70.27 & 70.96 & 71.42 & 70.64 \\
Bengkulu & 68.06 & 68.59 & 69.33 & 69.95 & 68.98 \\
Central Java & 68.78 & 69.49 & 69.98 & 70.52 & 69.69 \\
Central Kalimantan & 67.77 & 68.53 & 69.13 & 69.79 & 68.81 \\
Central Sulawesi & 66.43 & 66.76 & 67.47 & 68.11 & 67.19 \\
DI Yogyakarta & 76.81 & 77.59 & 78.38 & 78.89 & 77.92 \\
DKI Jakarta & 78.39 & 78.99 & 79.60 & 80.06 & 79.26 \\
East Java & 68.14 & 68.95 & 69.74 & 70.27 & 69.28 \\
East Kalimantan & 73.82 & 74.17 & 74.59 & 75.12 & 74.43 \\
East Nusa Tenggara & 62.26 & 62.67 & 63.13 & 63.73 & 62.95 \\
Gorontalo & 65.17 & 65.86 & 66.29 & 67.01 & 66.08 \\
Jambi & 68.24 & 68.89 & 69.62 & 69.99 & 69.19 \\
Lampung & 66.42 & 66.95 & 67.65 & 68.25 & 67.32 \\
Maluku & 66.74 & 67.05 & 67.60 & 68.19 & 67.40 \\
Nanggroe Aceh Darussalam & 68.81 & 69.45 & 70.00 & 70.60 & 69.72 \\
North Maluku & 65.18 & 65.91 & 66.63 & 67.20 & 66.23 \\
North Sulawesi & 69.96 & 70.39 & 71.05 & 71.66 & 70.77 \\
North Sumatera & 68.87 & 69.51 & 70.00 & 70.57 & 69.74 \\
Papua & 56.75 & 57.25 & 58.05 & 59.09 & 57.79 \\
Riau & 70.33 & 70.84 & 71.20 & 71.79 & 71.04 \\
Riau Islands & 73.40 & 73.75 & 73.99 & 74.45 & 73.90 \\
South East Sulawesi & 68.07 & 68.75 & 69.31 & 69.86 & 69.00 \\
South Kalimantan & 67.63 & 68.38 & 69.05 & 69.65 & 68.68 \\
South Sulawesi & 68.49 & 69.15 & 69.76 & 70.34 & 69.44 \\
South Sumatera & 66.75 & 67.46 & 68.24 & 68.86 & 67.83 \\
West Sulawesi & 62.24 & 62.96 & 63.60 & 64.30 & 63.28 \\
West Java & 68.80 & 69.50 & 70.05 & 70.69 & 69.76 \\
West Kalimantan & 64.89 & 65.59 & 65.88 & 66.26 & 65.66 \\
West Nusa Tenggara & 64.31 & 65.19 & 65.81 & 66.58 & 65.47 \\
West Papua & 61.28 & 61.73 & 62.21 & 62.99 & 62.05 \\
West Sumatera & 69.36 & 69.98 & 70.73 & 71.24 & 70.33 \\
Average Total & 67.96 & 68.57 & 69.16 & 69.75 & 68.86 \\
\hline Sourc: & & & & &
\end{tabular}

Source: Indonesia Statistic Bureau (2018)

Consistent with the findings for the Islamic financial inclusion index, DKI Jakarta is the leader in human development progress among other provinces in Indonesia. This is plausible since Jakarta, as the capital of Indonesia, has a more comprehensive infrastructure, a better education system and adequate healthcare facilities. On average, DKI Jakarta recorded an HDI of 79.26 during the period 2014-2017. In contrast, Papua had the lowest average HDI at only 57.79. Although 
the government has paid serious attention to the development of infrastructure projects in Papua, its HDI level remains far behind that of Java island.

Looking at the Pearson's correlation and scatter plot in Table 6, we can infer that the Islamic financial inclusion index is significant, displaying a positive correlation with the HDI. The correlation coefficient of 0.4332 significant at the $10 \%$ level shows a positive correlation between the two indexes. In other words, the high level of Islamic financial inclusion leads to an increase in the level of human development capacities. Provinces with high scores on the Islamic financial inclusion index are likely to have higher HDI. As shown in Figure 7, DKI Jakarta, East Java and Nanggroe Aceh Darussalam, which together make up the top 3 for Islamic financial inclusion, are likely to have a better HDI. This finding suggests that the presence of Islamic banks in Indonesia contributes positively to economic growth, promotes better access to education and increases the standard of living.

Table 6.

Pairwise Correlation

\begin{tabular}{lcc}
\hline & IFI & HDI \\
\hline IFI & 1 & \\
HDI & $0.4332^{*}$ & 1 \\
\hline
\end{tabular}

Figure 7. Scatter Plot of IFI Index and HDI across 33 Provinces in Indonesia

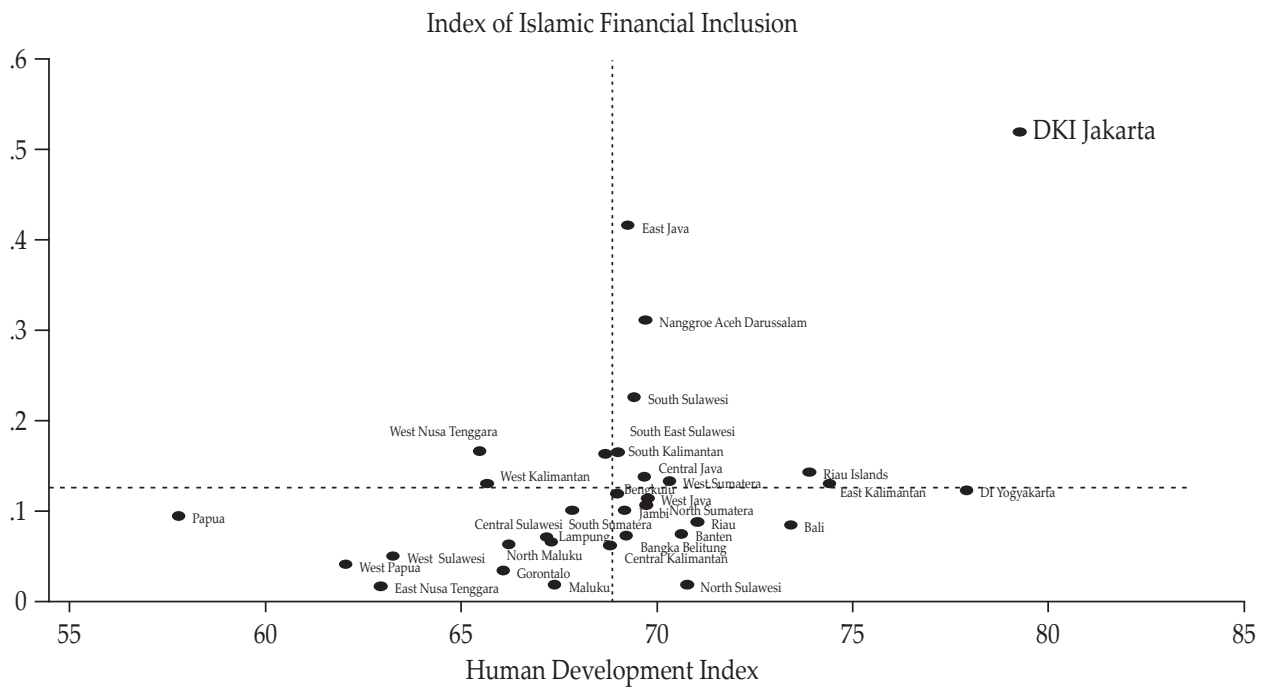

Source: author's calculation (2018) 


\section{CONCLUSION AND RECOMMENDATIONS}

\subsection{Conclusion}

This study has measured Islamic financial inclusion in Indonesia based on the three dimensions of accessibility, availability and usage of Islamic banking services. Overall, the study concludes that the level of Islamic financial inclusion in Indonesia remains low, particularly in the eastern part of the country, although the trend over the period of the study showed a positive increase. The measurement of the Islamic financial inclusion index across the 33 provinces also indicates that DKI Jakarta had the highest average score with respect to Islamic financial inclusion, followed by East Java and Nanggroe Aceh Darussalam. In contrast, East Nusa Tenggara had the lowest average score on the Islamic financial inclusion index.

In particular, there was a gradual uptrend in the accessibility aspect from 2014 to 2017, as reflected by the average values of third-party funds of Islamic banks (Islamic commercial banks and Islamic business units). Here, DKI Jakarta had the highest rank for accessibility, followed by the East Java region. In contrast, North Sulawesi was the region with the lowest level of accessibility. In terms of the availability dimension, the study reveals that, on average, there is one (1) Islamic banking institution to serve up to 100,000 people in Indonesia. East Java appears to have the highest Islamic banking penetration level, followed by DKI Jakarta and Nanggroe Aceh Darussalam. As for the usage dimension, there was variation among the 33 provinces in Indonesia in terms of the use of Islamic banking services. Nanggroe Aceh Darussalam recorded the highest usage of Islamic banking services, followed by DKI Jakarta and South Sulawesi. On the other hand, East Nusa Tenggara saw the lowest usage of Islamic banking services. On the whole, the study found that both the usage and availability dimensions played a more instrumental role in Islamic financial inclusion in Indonesia than the accessibility aspect.

The study also found that the Islamic financial inclusion index has a positive correlation with the HDI. The correlation coefficient of 0.4332 significant at the $10 \%$ level signifies a positive correlation between the two indexes. In other words, the high level of Islamic financial inclusion leads to an increase in the level of human development capacities. Provinces with a high score on the Islamic financial inclusion index are likely to have higher HDI. In this regard, DKI Jakarta leads in human development progress among other provinces in Indonesia. In contrast, Papua has the lowest average HDI.

\subsection{Recommendations}

The findings of the study suggest the following:

1. The government should pay serious attention to increasing the usage and availability aspects of Islamic financial inclusion, especially in the eastern part of Indonesia, such as East Nusa Tenggara and Papua, through supportive regulation and infrastructure.

2. The government should also provide a conducive legal and regulatory framework, such as incentives, to create a level playing field for the Islamic financial industry in support of the country's financial inclusion agenda.

3. The government should consider Islamic finance as the main engine for 
developing the country's economy, increasing wealth and prosperity and promoting better access to education. This is particularly true given the positive correlation between the IFI and HDI.

4. The Islamic financial industry should play a greater role in improving financial access for the low-income segment by providing adequate supporting infrastructure so that services can be easily accessed by all, including the underserved and poor.

5. Further empirical research using primary data is needed in order to develop a better understanding and a more objective measurement of the financial inclusion index in Indonesia. The use of other analytical tools such as Structural Equation Modelling (SEM) and Analytic Network Process (ANP) will provide more input to the regulators and IFIs for use in formulating appropriate policies and strategies aimed at enhancing the level of financial inclusion in Indonesia.

\section{REFERENCES}

Allen, F., Demirguc-Kunt, A., Klapper, L, \& Peria, M. S. M. (2012). The Foundations of Financial Inclusion: Understanding Ownership and use of Formal Accounts. Policy Research Working Paper 6290. The World Bank Development Research Group Finance and Private Sector Development Team.

Bongomin, G. O. C., Munene, J. C., Ntayi, J. M., \& Maling, C. A. (2018). Nexus between Financial Literacy and Financial Inclusion: Examining the Moderating Role of Cognition from a Developing Country Perspective. International Journal of Bank Marketing, 36(7), 1190-1212.

Chee, J. (2015). Pearson's Product Moment Correlation: Sample Analysis. University of Hawaii at Mānoa School of Nursing.

Dupas, P., \& Robinson, J. (2013). Savings Constraints and Microenterprise Development: Evidence from a Field Experiment in Kenya. American Economic Journal: Applied Economics, 5(1), 163-192.

Kimutai, B. J. (2015). Factors Influencing Financial Inclusion in Rural Kenya: A case Study of Kenya Commercial Bank Agent Outlets in Marakwet West Sub County. (Unpublished master's thesis). University of Nairobi, Kenya.

Kunt, A. D., \& Klapper, L. (2012). Measuring Financial Inclusion: The Global Findex Database. Policy Research Working Paper. The World Bank Development Research Group. Finance and Private Sector Development Team, April 2012.

Kunt, A. D., \& Klapper, L. (2013). Measuring Financial Inclusion: Explaining Variation in Use of Financial Services across and within Countries. Brookings Papers on Economic Activity, Spring 2013.

Mohieldin, M., Iqbal, Z., Rostom, A., \& Fu, X. (2011). The role of Islamic Finance in Enhancing Financial Inclusion in Organization of Islamic Cooperation (OIC) Countries. Policy Research Working Paper 5920. The World Bank Development Research Group. Finance and Private Sector Development Team, December 2011.

Naceur, S. B., Barajas, A., \& Massara, A. (2015). Can Islamic Banking increase Financial Inclusion? IMF Working Paper WP/15/31, February 2015. 
Sanjaya, I., \& Nursechafia (2016). Keuangan inklusif dan Pertumbuhan Inklusif: Analisis Antar Provinsi di Indonesia. Buletin Ekonomi Moneter dan Perbankan, 18(3).

Sarma, M. (2012). Index of Financial Inclusion - A Measure of Financial Sector Inclusiveness. Berlin Working Papers on Money, Finance, Trade and Development, No.7, p.1-34.

Umar, A. (2017). Index of Syariah Financial Inclusion in Indonesia. Buletin Ekonomi Moneter dan Perbankan, 20(1).

Zins, A., \& Weill, L. (2016). The Determinants of Financial Inclusion in Africa. Review of Development Finance, 6, 46-57. 